\title{
Robust neutralising activity and activation of neutrophil cytotoxic responses mediated by antibodies targeting the HTLV-1 envelope glycoprotein
}

\author{
Chien-Wen Kuo, Lindsay Tulloch, David W Brighty* \\ From 15th International Conference on Human Retroviruses: HTLV and Related Viruses \\ Leuven and Gembloux, Belgium. 5-8 June 2011
}

Infection of human cells by Human T-cell leukaemia virus (HTLV-1) is mediated by the viral envelope glycoproteins. The gp46 surface glycoprotein binds to a cell surface receptors, including heparan sulphate proteoglycans, neuropilin-1, and Glut-1, allowing the transmembrane glycoprotein to initiate fusion of the viral and cellular membranes. The envelope glycoproteins are recognised by neutralising antibodies and cytotoxic $\mathrm{T}$ lymphocytes following a protective immune response, and therefore represent attractive components for an HTLV-1 vaccine. Here we begin to explore the immunological properties of recombinant $\mathrm{SU}$ as a potential subunit vaccine candidate. We have used a soluble recombinant gp46 fused to the Fc-region of human IgG (sRgp46-Fc) as an immunogen to vaccinate mice and generate monoclonal antibodies (mAbs) targeting SU. The recombinant SU protein is highly immunogenic, inducing high titre antibody responses to the immunogen and facilitating selection of hybridomas that secrete anti-SU mAbs. Many of these mAbs recognise envelope expressed by HTLV-1 infected cells and these antibodies strongly stimulate neutrophil-mediated cytotoxic responses. Moreover, several of the mAbs directly and robustly antagonise envelope-mediated fusion and neutralize pseudovirus infectivity. While antibodies targeting either the receptor-binding domain or C-terminal domain of SU exhibit anti-viral activity, the most potently neutralizing $\mathrm{mAbs}$ tend to recognise epitopes that cluster in the $\mathrm{N}$-terminal receptor-binding domain

\footnotetext{
* Correspondence: d.w.brighty@dundee.ac.uk
}

The Biomedical Research Institute, College of Medicine Dentistry and Nursing, Ninewells Hospital, Dundee, DD1 9SY, UK of SU. Thus, our data demonstrate that recombinant forms of SU possess immunological features that are of direct utility to subunit vaccine design.

Published: 6 June 2011

\section{doi:10.1186/1742-4690-8-S1-A170}

Cite this article as: Kuo et al:: Robust neutralising activity and activation of neutrophil cytotoxic responses mediated by antibodies targeting the HTLV-1 envelope glycoprotein. Retrovirology 2011 8(Suppl 1):A170.
Submit your next manuscript to BioMed Central and take full advantage of:

- Convenient online submission

- Thorough peer review

- No space constraints or color figure charges

- Immediate publication on acceptance

- Inclusion in PubMed, CAS, Scopus and Google Scholar

- Research which is freely available for redistribution
C Biomed Central 